\title{
Use of Image Analysis for Monitoring the Dilution of Physalis peruviana Pulp
}

\author{
Silvana Licodiedoff ${ }^{1}$, Rosemary Hoffmann Ribani ${ }^{1}$, Ana Mery de Oliveira Camlofski ${ }^{1}$ and \\ Marcelo Kaminski Lenzi ${ }^{2 *}$ \\ ${ }^{1}$ Programa de Pós-Graduação em Engenharia de Alimentos; Universidade Federal do Paraná; CP: 19011; 81531- \\ 980; Curitiba - PR - Brasil. ${ }^{2}$ Departamento de Engenharia Química; Universidade Federal do Paraná; CP: 19011; \\ 81531-980; Curitiba - PR - Brasil
}

\begin{abstract}
The aim of this work was to develop linear models using the image analysis coupled with density measurements to monitor the dilution of the Physalis juice in the concentrations ranging from 0 to $100 \%$ in mass of juice pulp. A sample corresponding to $20 \%$ in the mass of juice pulp was for validating purposes and a prediction of $19.9 \pm 0.3 \%$. The models with three parameters showed the best predictions, providing this technique with a promising future for the monitoring the dilution of fruit juices.
\end{abstract}

Key words: Juice, fruit, color, image, RGB, Physalis

\section{INTRODUCTION}

Physalis is a fruit belonging to Solanaceae family and commonly found in temperate, subtropical regions throughout the world. In Brazil, the state of Rio Grande do Sul is the main producer of Physalis, especially angulata and peruviana (Agra et al. 2009; Peixoto et al. 2010). The sale of this fruit in local markets has attracted the interest of different scale producers, since a fast growing demand has been observed. This has happened due to some of its key nutritional features such as high levels of antioxidants and cancer fighting and also as food supplementation (Chaves et al. 2008).

Physalis peruviana is largely sold as fresh fruit, usually packed inboxes of roughly $450 \mathrm{~g}$ covered with thin transparent plastic film. This form of distribution may, however, reduce the fruit shelf life. There are not many studies on post-harvest storage of this fruit, which is critical in keeping the fruit quality and extending its shelf life.
Industrialization and processing can contribute to enlarge the diversity of the fruit distribution ways, in particular the production of fruit juices (Sancho et al. 2007).

Fruit juices are consumed and appreciated as natural sources of carbohydrates, carotenoids, vitamins, minerals and other important components (Sandi et al. 2004; Pinheiro et al. 2006; Mosqueda-Melgar et al. 2011; Granato et al. 2011). The color of the juice represents an important feature for marketing purposes. It is mainly influenced by the concentration, especially in citrus fruits, and color also represents an important attribute of quality classification (Marques et al. 2004) and acceptability of purchase (Pace et al. 2001; Meléndez-Martínez et al. 2005; Ulloa et al. 2007; Meléndez-Melgar et al. 2011).

In order to analyze and characterize the fruit-based product properties, industry commonly uses typical physicochemical analyses such as density,

\footnotetext{
*Author for correspondence: lenzi@ufpr.br
} 
viscosity, specific heat, thermal conductivity, etc. Techniques such as spectrophotometry, colorimetry (Eagerman, 1978; Moura et al. 2005), capillary electrophoresis with contactless conductivity detection (Petr et al. 2011), gas chromatography-mass spectrometry (GC-MS) are also used. Besides the high cost, these techniques usually present long time delays, or require the use of several purification steps (Perez-Cachopilar, 2011; Nitra, 2011). Sensory analysis is another methodology used to evaluate the juice dilution; however, it usually requires a large number of variables and a trained team, which is generally very time consuming and presents high costs (Granitto et al. 2007).

Image analysis represents an important characterization technique in food science and technology (Fernandes et al. 2013), not only due to its precision / accuracy, but also because of its non-invasive feature. These characteristics, coupled to negligible time delay, provide a wide range of applications, as characterization occurs by the analysis of image graphical elements, named pixels (Lupetti et al. 2005; Blasco et al. 2009). Some important applications regarding the use of image analysis for fruit characterization include fruits and vegetables classification in/during the storage (Perera, 2010; Cubero et al. 2011). Fernandez-Vazquez et al. (2011) reported the correlation between the instrumental and sensory evaluation in orange juice. Martin et al. (2007) evaluated the color of different wines using a panel of eight observers, a tele-spectroradiometry and a digital camera. Their report indicated that the two analytical methods led to approximately the same results. Consequently, image analysis was reported to be a successful approach of obtaining digital measurement of the wine color by a non-invasive method. Thus, image analysis represents an important alternative tool for the study and characterization of both the concentrated and diluted fruit juices. Therefore, this work aimed to develop and validate an image-analysis-based technique coupled to typical physicochemical analysis in order to monitor the dilution of Physalis Peruviana "in natura" concentrated juice pulp.

\section{MATERIALS AND METHODS}

\section{Materials}

Physalis peruviana fruits, provided by the Italbraz ${ }^{\circledR}$, Vacaria-Brazil, were transported and stored at $7.0 \pm 0.5^{\circ} \mathrm{C}$. Selected fruits had their natural protection capsule removed and were individually weighed before preparing the juice pulp, which was obtained after processing the fruits for $3 \mathrm{~min}$ at $25,000 \mathrm{rpm}$ in a food multiprocessor (MR2100 system Polytron, Kinematica, AG Lucerne, Switzerland). The juice pulp was labeled as sample M100, as it contained $100 \%$ of Physalis "in natura" juice pulp. The sample M0 contained only water. Each intermediate sample was prepared by adding water to the juice pulp according to percentages shown in Table 1, leading to a final composition in a mass basis. The sample containing $20 \%$ of juice pulp was used for validation purposes only. For sample preparation, an analytical balance (Bio Precisa model: FA 2104N, accuracy: 0.0001) was used.

Table 1 - Sample composition (mass percentage of Physalis juice pulp).

\begin{tabular}{cccccccccc}
\hline $\boldsymbol{M 0}$ & $\boldsymbol{M 5}$ & $\boldsymbol{M 1 0}$ & $\boldsymbol{M 2 0}$ & $\boldsymbol{M 3 5}$ & $\boldsymbol{M 5 0}$ & $\boldsymbol{M 6 0}$ & $\boldsymbol{M 7 0}$ & $\boldsymbol{M 8 0}$ & $\boldsymbol{M 1 0 0}$ \\
\hline 0 & 5 & 10 & 20 & 35 & 50 & 60 & 70 & 80 & 100 \\
\hline
\end{tabular}

\section{Image Analysis}

From the $50 \cdot 10^{-3} \mathrm{~L}$ quantity of each sample, $4.5 \cdot 10^{-}$

${ }^{3} \mathrm{~L}$ were individually transferred to a different polystyrene cuvette (Kartell SPA, Italy) with $10^{-}$ ${ }^{2} \mathrm{~m}$ of light path. All the samples were placed in an appropriate chamber in order to reduce any possible environmental interference and provide all the samples with the same illumination intensity. Photographs were taken using an Olympus (Model: D-595) camera, with zoom fixed at $1 \mathrm{x}$ and positioned $0.3 \mathrm{~m}$ away from the cuvette containing the samples, aimed at framing all the cuvettes in the same shot. The images were processed by a multi-task software (Fernandes et al. 2012), using the RGB color system (Gonzalez and Woods, 2002; Khatchatourian and Padilha, 2008). From each sample, a set of 16,000 pixels was selected and for each pixel of each set, red $(\mathrm{R})$, green $(\mathrm{G})$ and blue (B) components were determined. This number of pixels was high 
enough not only to assure a robustness feature to the image analysis procedure considered, but also to lead to a short confidence interval for each color component of each sample.

\section{Physicochemical Analyses}

After taking the necessary pictures, other typical physicochemical analyses were performed. Density measurements were carried out using a density meter ANTON - PARR (Model: DMA $5000)$ with measurement range of $0-3 \mathrm{~g} / \mathrm{cm}^{3}$ and resolution of $10^{-6} \mathrm{~g} / \mathrm{cm}^{3}$. Electrical conductivity was measured with a BUNKER conductivity meter of range $0-1999 \mu \mathrm{S} / \mathrm{cm}$ and resolution of $10^{-}$ ${ }^{1} \mu \mathrm{S} / \mathrm{cm}$. Viscosity measurements were obtained using a Brookfield equipment (Model: RVII+Pro), coupled to the software Rheocalc (Version: V3.1-1), using $10^{-3} \mathrm{mPa} \cdot \mathrm{s}$ of resolution. Finally, total soluble solids as ${ }^{\circ}$ Brix (TSS) was evaluated using a refractometer RL3 (Polskie Zaklandy Optyczne S.A.) with measurement range of $0-90{ }^{\circ} \mathrm{Brix}$, with resolution $10^{-2}{ }^{\circ} \mathrm{Brix}$. All the analyses were carried out in triplicates.

\section{Parameter Estimation}

The mass percentage content of Physalis juice pulp was correlated to average values of image analysis component $\mathrm{R}$, component $\mathrm{G}$, component $\mathrm{B}$, density (dens), electrical conductivity (cond), viscosity (visc) and total soluble solids content (brix), in order to develop a calibration curve of the dilution monitoring system. Concerning the parameter estimation, the sum of square of the distances between the model predictions and experimental values was considered as the objective function. The parameter estimation task was an optimization problem, which consisted in calculating the set of parameters that led to the minimum value of the objective function. This problem was numerically solved with the aid of a Levenberg-Marquadt-based method (Levenberg, 1944; Marquadt, 1963) using $10^{-7}$ as convergence criteria and 1.5 as initial guess. The statistical validation was performed as previously reported by Isfer et al. (2010).

The sample M20 was not used for parameter estimation; it was only used for validation purposes. Finally, not only parameter variance and covariance, but also image analysis and physicochemical variances were considered for evaluating the model uncertainty of a given prediction, as shown Eq. (01).

$$
s_{\text {mass }}=\sqrt{\sum_{i=1}^{N P}\left(\frac{\partial m a s s}{\partial a i}\right)^{2} \cdot s_{a i}^{2}+2 \cdot \sum_{i=1}^{N P-1} \sum_{j=i+1}^{N P}\left(\frac{\partial m a s s}{\partial a i}\right) \cdot\left(\frac{\partial m a s s}{\partial a j}\right) \cdot s_{a i-a j}^{2}}
$$

where: NP is the number of variables and parameters; $s_{a i}^{2}$ is the variance of parameter or variable $\boldsymbol{a}_{i} ; \mathrm{s}_{\mathrm{ai}-\mathrm{aj}}^{2}$ is the covariance of parameters or variables $\boldsymbol{a}_{i}$ and $\boldsymbol{a}_{j}$.

\section{RESULTS AND DISCUSSION}

Figure 1 presents the juice samples used in this study. A gradient color was generated according to the dilution level, as the higher the juice pulp amount, the darker the sample was.

Table 2 presents the mean and standard error results concerning image analysis components $\mathrm{R}$, $\mathrm{G}$ and $\mathrm{B}$. It was observed that the standard error values were low not only due to the large number of pixels selected, but also due to the low variability of the pixel color components within a single sample, indicating a good sample homogeneity and dilution. Table 3 presents the other typical physicochemical analyses results, also showing low standard error values, with the exception of viscosity analysis. Higher viscosity deviations probably occurred due to temperature variations during the analysis as triplicate analyzes were carried out in a row for each sample and the used viscosity meter did not have a temperature controller.

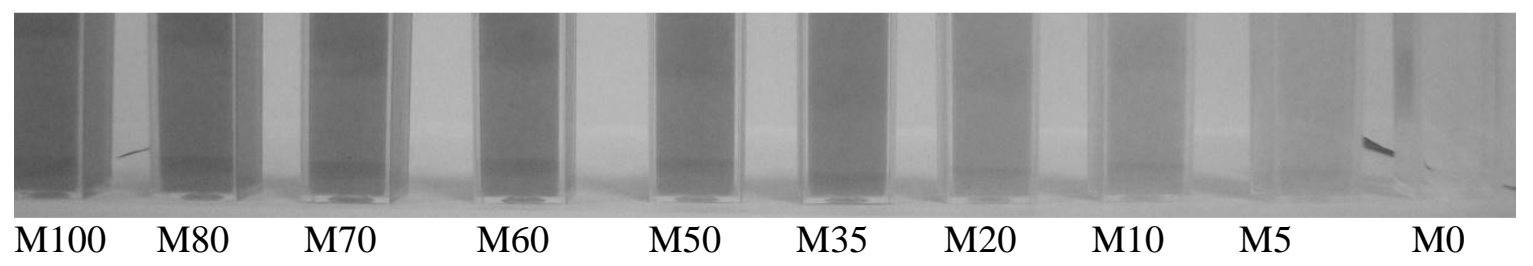

Figure 1 - Juice samples. 
Table 2 - Image analysis ( $R, G, B)$ results.

\begin{tabular}{cccc}
\hline Sample & $\mathbf{R}$ & $\mathbf{G}$ & $\mathbf{B}$ \\
\hline M0 & $151.69 \pm 0.03$ & $154.70 \pm 0.03$ & $159.84 \pm 0.03$ \\
M5 & $159.58 \pm 0.02$ & $156.95 \pm 0.04$ & $122.32 \pm 0.03$ \\
M10 & $173.41 \pm 0.02$ & $156.99 \pm 0.04$ & $69.72 \pm 0.03$ \\
M20 & $173.40 \pm 0.02$ & $156.91 \pm 0.04$ & $69.11 \pm 0.02$ \\
M35 & $175.82 \pm 0.02$ & $141.54 \pm 0.07$ & $33.18 \pm 0.02$ \\
M50 & $174.98 \pm 0.03$ & $137.90 \pm 0.08$ & $37.45 \pm 0.03$ \\
M60 & $172.26 \pm 0.03$ & $131.01 \pm 0.07$ & $32.48 \pm 0.03$ \\
M70 & $166.63 \pm 0.03$ & $124.28 \pm 0.06$ & $27.66 \pm 0.03$ \\
M80 & $156.18 \pm 0.03$ & $113.18 \pm 0.04$ & $25.55 \pm 0.03$ \\
M100 & $145.88 \pm 0.03$ & $104.40 \pm 0.04$ & $26.30 \pm 0.03$ \\
\hline
\end{tabular}

Table 3 - Other analysis results.

\begin{tabular}{ccccc}
\hline Sample & cond $(\mu \mathrm{S} / \mathrm{cm})$ & brix $\left({ }^{\circ} \mathrm{Brix}\right)$ & dens $\left(\mathrm{g} / \mathrm{cm}^{3}\right)$ & vise $(\mathrm{mPa} \cdot \mathrm{s})$ \\
\hline M0 & $20 \pm 0.1$ & $0.00 \pm 0.00$ & $0.998169 \pm 0.000003$ & $2.2 \pm 0.2$ \\
M5 & $662.9 \pm 0.3$ & $1.02 \pm 0.02$ & $1.00145 \pm 0.00005$ & $2.9 \pm 0.6$ \\
M10 & $1213.0 \pm 0.7$ & $1.88 \pm 0.07$ & $1.0055 \pm 0.0001$ & $4.6 \pm 1.0$ \\
M20 & $2185.0 \pm 2.9$ & $3.62 \pm 0.07$ & $1.01284 \pm 0.00007$ & $6.9 \pm 1.7$ \\
M35 & $3377.5 \pm 11.1$ & $5.93 \pm 0.09$ & $1.0237 \pm 0.0002$ & $13.7 \pm 3.1$ \\
M50 & $4422.5 \pm 8.5$ & $8.50 \pm 0.06$ & $1.03581 \pm 0.00003$ & $21.2 \pm 3.9$ \\
M60 & $5472.5 \pm 27.5$ & $10.53 \pm 0.03$ & $1.0436 \pm 0.0002$ & $25.0 \pm 7.1$ \\
M70 & $5542.5 \pm 11.8$ & $12.23 \pm 0.09$ & $1.0523 \pm 0.0008$ & $43.3 \pm 9.3$ \\
M80 & $5645.0 \pm 19.4$ & $13.80 \pm 0.12$ & $1.05877 \pm 0.00005$ & $87 \pm 16$ \\
M100 & $5915.0 \pm 23.3$ & $16.93 \pm 0.09$ & $1.0751 \pm 0.0004$ & $240 \pm 23$ \\
\hline
\end{tabular}

For modeling purposes, different types of linear models containing three and four parameters were developed, aimed at mass percentage of juice pulp in each sample prediction. The number of parameters was chosen in order to avoid overparameterization and experimental error fitting. Table 4 presents a summary of the best developed models and parameter estimation tasks, containing the values of the objective function, correlation coefficient (r), parameters estimates, parameters standard deviation and covariance estimates. All the models presented " $r$ " values roughly equal to 1 and low values of the objective function indicating that the model predictions were close to the experimental data. It would be important to emphasize that the reported models presented parameters estimates that were higher than their respective standard error, indicating the parameter statistical significance. It also must be stressed that several models were assembled by the combination of the image analysis components $\mathrm{R}$, $\mathrm{G}, \mathrm{B}$ and the physicochemical analysis, but only the models presented in Table 1 had higher " $\mathrm{r}$ " value and parameters with statistical significance. This modeling procedure was also adopted by Ochoa Martínez et al. (2004) to study the mixtures of jalapeño pepper.

Figure 2 presents the residual values of selected models from Table 4. On average, model P4M1 presented the lowest residual values as it contained more parameters and also the lowest value of the objective function. 
Table 4 - Summary of parameter estimation.

\begin{tabular}{|c|c|c|c|}
\hline Parameters & \multicolumn{3}{|c|}{ Model } \\
\hline \multirow{5}{*}{3} & Model label: P3M1 & & \\
\hline & \multicolumn{3}{|c|}{ Model equation: mass $=\mathrm{a} 0+\mathrm{a} 1 \cdot \operatorname{cond}+\mathrm{a} 2 \cdot \mathrm{dens}$} \\
\hline & Objective Function: 2.0 & $\mathrm{r}=0.999$ & \\
\hline & Parameters & Parameter Covariance & \\
\hline & $\begin{array}{l}\mathrm{a} 0=(-121.0 \pm 2.6) \cdot 10^{+1} \\
\mathrm{a} 1=(+10.9 \pm 3.0) \cdot 10^{-4} \\
\mathrm{a} 2=(+121.3 \pm 2.6) \cdot 10^{+1}\end{array}$ & $\begin{array}{l}(\mathrm{a} 0-\mathrm{a} 1)=+7.50 \cdot 10^{-3} \\
(\mathrm{a} 0-\mathrm{a} 2)=-6.82 \cdot 10^{+2} \\
(\mathrm{a} 1-\mathrm{a} 2)=-7.59 \cdot 10^{-3}\end{array}$ & \\
\hline \multirow{5}{*}{3} & Model label: P3M2 & & \\
\hline & Model equation: mass $=$ & $\mathrm{sc}+\mathrm{a} 2 \cdot \mathrm{dens}$ & \\
\hline & Objective Function: 2.5 & $\mathrm{r}=0.999$ & \\
\hline & Parameters & Parameter Covariance & \\
\hline & $\begin{array}{l}\mathrm{a} 0=(-133.2 \pm 1.3) \cdot 10^{+1} \\
\mathrm{a} 1=(-13.3 \pm 4.2) \cdot 10^{-3} \\
\mathrm{a} 2=(+133.6 \pm 1.3) \cdot 10^{+1}\end{array}$ & $\begin{array}{l}(\mathrm{a} 0-\mathrm{a} 1)=+4.52 \cdot 10^{-2} \\
(\mathrm{a} 0-\mathrm{a} 2)=-1.82 \cdot 10^{+2} \\
(\mathrm{a} 1-\mathrm{a} 2)=-4.47 \cdot 10^{-2}\end{array}$ & \\
\hline \multirow{5}{*}{3} & Model label: P3M3 & & \\
\hline & Model equation: mass $=$ & ens $+a 2 \cdot R$ & \\
\hline & Objective Function: 2.6 & $\mathrm{r}=0.999$ & \\
\hline & Parameters & Parameter Covariance & \\
\hline & $\begin{array}{l}\mathrm{a} 0=(-131.7 \pm 1.1) \cdot 10^{+1} \\
\mathrm{a} 1=(+131.0 \pm 0.9) \cdot 10^{+1} \\
\mathrm{a} 2=(+6.5 \pm 2.2) \cdot 10^{-2}\end{array}$ & $\begin{array}{l}(\mathrm{a} 0-\mathrm{a} 1)=-8.85 \cdot 10^{+1} \\
(\mathrm{a} 0-\mathrm{a} 2)=-1.27 \cdot 10^{-1} \\
(\mathrm{a} 1-\mathrm{a} 2)=+4.88 \cdot 10^{-2}\end{array}$ & \\
\hline \multirow{5}{*}{3} & Model label: P3M4 & & \\
\hline & Model equation: mass $=$ & ens+a2 brix & \\
\hline & Objective Function: 2.8 & $\mathrm{r}=0.999$ & \\
\hline & Parameters & Parameter Covariance & \\
\hline & $\begin{array}{l}\mathrm{a} 0=(-6.4 \pm 1.9) \cdot 10^{+2} \\
\mathrm{a} 1=(+6.5 \pm 2.0) \cdot 10^{+2} \\
\mathrm{a} 2=(+29.6 \pm 9.0) \cdot 10^{-1}\end{array}$ & $\begin{array}{l}(\mathrm{a} 0-\mathrm{a} 1)=-3.99 \cdot 10^{+4} \\
(\mathrm{a} 0-\mathrm{a} 2)=+1.79 \cdot 10^{+2} \\
(\mathrm{a} 1-\mathrm{a} 2)=-1.80 \cdot 10^{+2}\end{array}$ & \\
\hline \multirow{5}{*}{3} & Model label: P3M5 & & \\
\hline & Model equation: mass $=$ & $+\mathrm{a} 2 \cdot \mathrm{cond}$ & \\
\hline & Objective Function: 2.7 & $\mathrm{r}=0.999$ & \\
\hline & Parameters & Parameter Covariance & \\
\hline & $\begin{array}{l}\mathrm{a} 0=(-3.5 \pm 2.8) \cdot 10^{-1} \\
\mathrm{a} 1=(+10.1 \pm 5.0) \cdot 10^{-3} \\
\mathrm{a} 2=(+57.5 \pm 0.7) \cdot 10^{-1}\end{array}$ & $\begin{array}{l}(\mathrm{a} 0-\mathrm{a} 1)=+8.25 \cdot 10^{-4} \\
(\mathrm{a} 0-\mathrm{a} 2)=-2.59 \cdot 10^{-2} \\
(\mathrm{a} 1-\mathrm{a} 2)=-2.74 \cdot 10^{-4}\end{array}$ & \\
\hline \multirow{4}{*}{3} & $\begin{array}{l}\text { Model label: P3M6 } \\
\text { Model equation: } \text { mass =a }\end{array}$ & -a2 dens & \\
\hline & Objective Function: 2.4 & $\mathrm{r}=0.999$ & \\
\hline & Parameters & Parameter Covariance & \\
\hline & $\begin{array}{l}\mathrm{a} 0=(-126.1 \pm 1.5) \cdot 10^{+1} \\
\mathrm{a} 1=(-24.7 \pm 7.8) \cdot 10^{-3} \\
\mathrm{a} 2=(+126.7 \pm 1.4) \cdot 10^{+1}\end{array}$ & $\begin{array}{l}(\mathrm{a} 0-\mathrm{a} 1)=-9.53 \cdot 10^{-2} \\
(\mathrm{a} 0-\mathrm{a} 2)=-2.09 \cdot 10^{+2} \\
(\mathrm{a} 1-\mathrm{a} 2)=+8.88 \cdot 10^{-2}\end{array}$ & \\
\hline \multirow{4}{*}{4} & $\begin{array}{l}\text { Model label: P4M1 } \\
\text { Model equation: } \text { mass = }\end{array}$ & $+\mathrm{a} 2 \cdot \mathrm{G}+\mathrm{a} 3 \cdot \mathrm{dens}$ & \\
\hline & Objective Function: 1.3 & $\mathrm{r}=0.999$ & \\
\hline & Parameters & Parameter Covariance & \\
\hline & $\begin{array}{l}\mathrm{a} 0=(-115.1 \pm 7.3) \cdot 10^{+1} \\
\mathrm{a} 1=(+11.3 \pm 2.7) \cdot 10^{-2} \\
\mathrm{a} 2=(-21.0 \pm 9.2) \cdot 10^{-2} \\
\mathrm{a} 3=(+116.9 \pm 6.2) \cdot 10^{+1}\end{array}$ & $\begin{array}{l}(\mathrm{a} 0-\mathrm{a} 1)=+1.46 \cdot 10^{0} \\
(\mathrm{a} 0-\mathrm{a} 2)=-6.68 \cdot 10^{0} \\
(\mathrm{a} 0-\mathrm{a} 3)=-4.54 \cdot 10^{+3}\end{array}$ & $\begin{array}{l}(\mathrm{a} 1-\mathrm{a} 2)=-1.95 \cdot 10^{+3} \\
(\mathrm{a} 1-\mathrm{a} 3)=-1.27 \cdot 10^{0} \\
(\mathrm{a} 2-\mathrm{a} 3)=+5.67 \cdot 10^{0}\end{array}$ \\
\hline
\end{tabular}




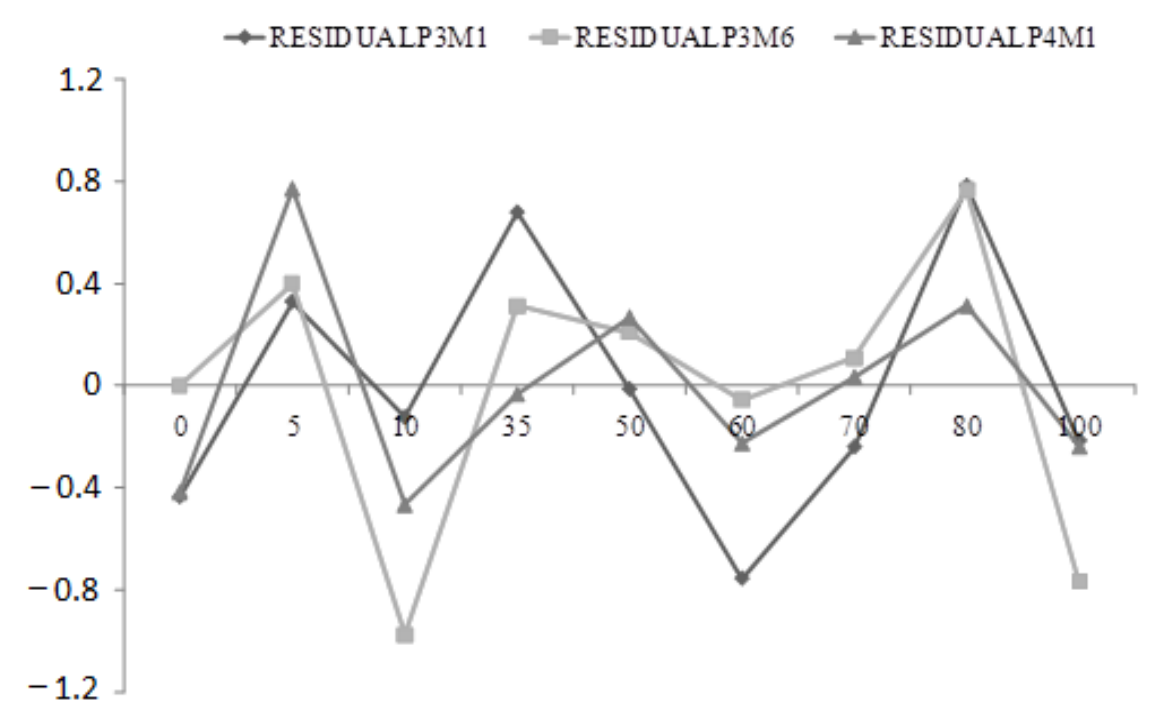

Figure 2 - Residual values of selected models.

As mentioned earlier, sample M20 was used for validation purposes only. Figure 3 presents the predictions of all the models reported in Table 4 and the respective uncertainty obtained with the aid of Eq. (01). Models P3M1, P3M2 and P3M4 used density coupled to electrical conductivity, viscosity and brix, respectively to obtain the predictions of $19.7 \pm 0.3,19.8 \pm 0.3$ and $19.7 \pm 0.3 \%$ of mass content of the juice pulp in the sample. These predictions could be regarded as very good as the experimental mass percentage value of juice pulp was $20 \%$ in the sample M20 with lower values of the prediction uncertainty. Models $\mathrm{P} 3 \mathrm{M} 3$, P3M5, P3M6 and P4M1 used the image analysis components as independent variables for predicting the percent content of the juice pulp in the sample M20, contrary to the models P3M1, $\mathrm{P} 3 \mathrm{M} 2$ and P3M4. The best prediction was obtained by the model P3M6, simultaneously keeping a low uncertainty value. This model indicated that image analysis provided better prediction values if its result was compared to the results of the models P3M1, P3M2 and P3M4 that contained typical physicochemical analysis coupled to density. This conclusion was also achieved by Godinho et al. (2008) when studying soft-drinks classification by the image analysis.

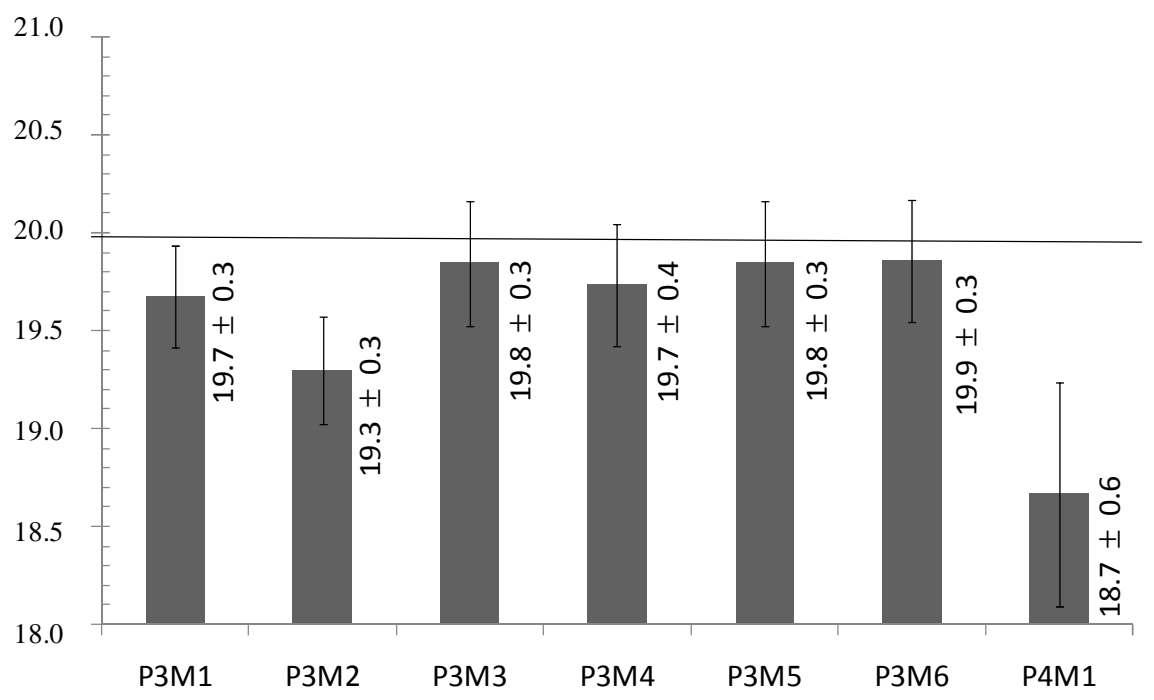

Figure 3 - Models predictions. 
The number of parameters plays a key role on the model behavior. Model P4M1 presented the lowest value of the objective function and the best data fitting, due to the higher number of parameters, but it led to the worst prediction. This probably happened because in this study, the use of four parameters was high enough to fit experimental error and not the actual data behavior itself. Consequently, an optimum number of parameters equal to three could be determined for this work.

\section{CONCLUSIONS}

In this work, image analysis, using RGB system, was proved to be an alternative tool for dilution monitoring, not only due to accuracy, but also because of short delays and non-invasive features. Developed linear models were able to predict the Physalis "in natura" juice content. A model using density and B component predicted the mass percent of juice pulp of the testing sample M20 of $20 \%$ as $19.9 \pm 0.3 \%$.

\section{ACKNOWLEDGEMENTS}

The authors thank to CNPq, CAPES and Fundação Araucária for financial support and for scholarships.

\section{REFERENCES}

Agra MF, Nurit-Silva K, Berger LR. Flora da Paraíba, Brasil: Solanum L (Solanaceae). Acta Bot Bras. 2009; 23: 826-842.

Blasco J, Cubero S, Gomez-Sanchis J, Mira P, Molto E. Development of a machine for the automatic sorting of pomegranate (Punicagranatum) arils based on computer vision. J Food Eng. 2009; 90: 27-34.

Bradley AE. Orange juice color measurement using general purpose tristimulus colorimeters. J Food Sci. 1978; 43: 428-430.

Chaves AC, Schuch MW, Erig AC. Estabelecimento e multiplicação in vitro de Physalis peruviana L. Cienc Agrotec. 2005; 29, 1281-1287.

Cubero S, Aleixos N, Molto E, Gomez-Sanchis J, Blasco J. Advances in machine vision applications for automatic inspection and quality evaluation of fruits and vegetables. Food Bioprocess Tech. 2011; 4, 487504.
Fernandes JK, Umebara T, Lenzi MK, Alves ETS. Image analysis for composition monitoring. Commercial blends of olive and soybean oil. Acta Sci-Technol. 2013, 35: 317-324.

Fernandez-Vazquez R, Stinco CM, Melendez-Martinez AJ, Heredia FJ, Vicario IM. Visual and instrumental evaluation of orange juice color: a consumers' preference study. J Sens Stud. 2011; 26: 436-444.

Godinho MS, Pereira RO, Ribeiro KO, Schimidt F, Oliveira AE. Classificação de refrigerantes através de análise de imagens e análise de componentes principais (PCA). Quim Nova. 2008; 31: 1485-1489.

Gonzalez RC, Woods RE. Digital image processing 2nd ed New York: Prentice Hall; 2002.

Granato D, De Castro IA, Piekarski FVBW, Beninca C, Masson ML. Influence of Passion Fruit Juice on Colour Stability and Sensory Acceptability of NonSugar Yacon-Based Pastes. Braz Arch Biol Technol. 2011; 54: 149-159.

Granitto PM, Gasperi F, Biasioli F, Trainotti E, Furlanello C. Modern data mining tools in descriptive sensory analysis: A case study with a random forest approach. Food Qual Pref. 2007; 18: 681-689.

Isfer LAD, Lenzi MK, Lenzi EK. Identification of biochemical reactors using fractional differential equations. Lat Am Appl Res. 2010; 40: 193-198.

Khatchatourian O, Padilha FRR. Reconhecimento de variedades de soja por meio do processamento de imagens digitais usando redes neurais artificiais. Eng Agric. 2008; 28: 759-769.

Levenberg K. A method for the solution of certain problems in least squares. Q Appl Math. 1944, 2: 164168.

Lupetti KO, Carvalho LC, Moura AF, Fatibello-Filho O. Análise de imagem em química analítica: empregando metodologias simples e didáticas para entender e prevenir o escurecimento de tecidos vegetais. Quim Nova. 2005; 28: 548-554.

Marquardt D. An algorithm for least-squares estimation of nonlinear parameters. SIAM J Appl Math. 1963; 11: 431-441.

Marques RMB, Atzingen MCV, Silva MEMP. Análisis sensorial y ácido ascórbico de hortaliza sem fresco y ultracongeladas. Cienc Tecnol Aliment. 2004; 4: 240245.

Martin MLGM, Wei J, Luo R, Hutchings J, Heredia FJ. Measuring colour appearance of red wines. Food Qual Pref. 2007; 18, 862-871.

Meléndez-Melgar AJ, Gómez-Robledo L, Vicario IM, Heredia FJ. Color of orange juices in relation to their carotenoid contents as assessed from different spectroscopic data. J Food Comp Anal. 2011; 24: 837-844. 
Meléndez-Martínez AJ, Vicaro IM, Heredia FJC. Correlation between visual and instrumental colour measurements of orange juice dilutions: effect of the background. Food Qual Pref. 2005; 16: 471-478.

Mosqueda-Melgar J, Raybaudi-Massilia RM, MartínBelloso O. Microbiological shelf life and sensory evaluation of fruit juices treated by high-intensity pulsed electric fields and antimicrobials. Food Bioprod Process. 2011; 54: 1-10.

Moura SCSR, França VCL, Leal AMCB. Propriedades termofísicas de soluções-modelo similares a suco Parte II. Ciencia Tecnol Alime. 2005; 25: 454-459.

Nitra N, Saowanit B, Plubplueng T. Rapid screening of antioxidant compounds in homemade fruit fermented juice using an on line LC-ESI-MS/MS and DPPH Assay. Chiang Mai J Sci. 2011; 38: 430-438.

Ochoa-Martínez LA, Gallegos-Infante JA, MoralesCastro J, Medrano-Roldán $\mathrm{H}$, Rocha-Guzmán, NE Mathematical model for prediction of moisture content in Jalapeño Pepper (Capsicum frutescens). Cienc Tecnol Aliment. 2004; 4: 154-157.

Pace B, Cefola M, Renna F, Attolico G. Relationship between visual appearance and browning as evaluated by image analysis and chemical traits in fresh-cut nectarines. Postharvest Biol Tec. 2011; 61: 178-183.

Peixoto N, Peixoto FC, Vaz UL, Neri SCM, Monteiro JG. Adubação orgânica e cobertura do solo no crescimento e produção de camapu. Hortic Bras. 2010; 28: 370-372.

Perera N, Gamage TV, Wakeling L, Gamlath GGS, Versteeg C. Colour and texture of apples high pressure processed in pineapple juice. Innov Food Sci Emerg. 2010; 11: 39-46.
Perez-Cachopilar R, Danyluk MD, Rouseff R. GC-MS quantification and sensory thresholds of guaiacol in orange juice and its correlation with Alicyclobacillus spp. Food Chem. 2011; 129: 45-50.

Petr T, Klara M, Eva S. Rapid monitoring of mono- and disaccharides in drinks, foodstuffs and foodstuff additives by capillary electrophoresis with contactless conductivity detection. Anal Chim Acta. 2011; 698: 1-5.

Pinheiro AM, Fernandes AG, Fai AEC, Prado GM, Sousa PHM, Maia GA. Avaliação química, físicoquímica e microbiológica de sucos de frutas integrais: abacaxi, caju e maracujá. Ciencia Tecnol Alime. 2006; 26: 98-103.

Sancho SO, Maia GA, Figueiredo RW, Rodrigues S, Sousa PHMS. Alterações químicas e físico-químicas no processamento de suco de caju (Anacardiumoccidentale L). Ciencia Tecnol Alime. 2007; 27: 878-882.

Sandi D, Chaves JBP, Sousa ACG, Parreiras JFM, Silva MTC, Constant PBL. Hunter color dimensions, sugar content and volatile compounds in pasteurized yellow passion fruit juice (Passifloraedulis var flavicarpa) during storage. Braz Arch Biol Technol. 2004; 47: 233-245.

Ulloa JA, Ulloa PR, Flores JR, Rangel BEU, Escalona H. Comportamiento del color embulbos del fruto de la jaca (ArtocarpusHeterophyllus) auto estabilizados en frascos de vidrio por la tecnología de obstáculos. Cienc Tecnol Aliment. 2007; 5: 372-378.
Received: April 11, 2012 ; Revised: October 09, 2012; Accepted: May 06, 2013. 